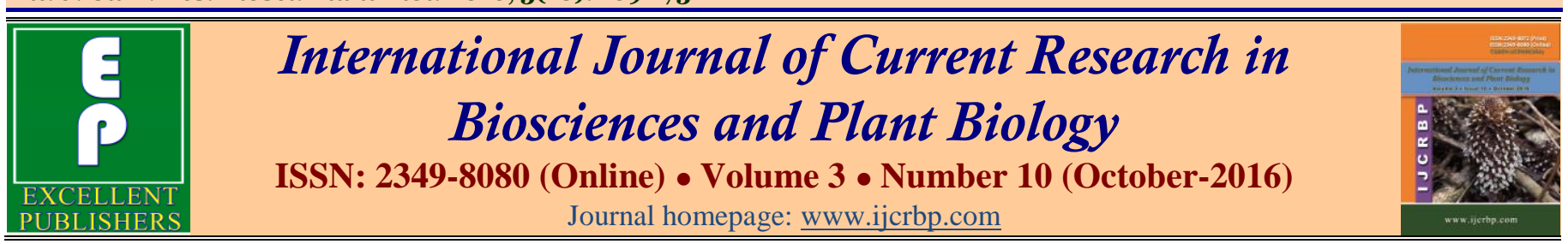

\title{
Phytochemical Screening and Hypoglycaemic Effect of Methanol Extract of Solanum anomalum Thonn. Fruits in Alloxan induced Hyperglycaemic and Normal Wistar Rats
}

\author{
Abubakar Bilyaminu ${ }^{*}$, Kwanashie Helen² and Zezi Abdulkadir Umar ${ }^{2}$ \\ ${ }^{1}$ Department of Pharmacology and Toxicology, Usmanu Danfodiyo University, Sokoto, Sokoto State, Nigeria \\ 'Department of Pharmacology and Therapeutics, Ahmadu Bello University, Zaria, Kaduna State, Nigeria
}

*Corresponding author.

\begin{abstract}
A b s tract
The study investigated the hypoglycaemic effect of methanol extract of Solanum anomalum fruit. Extraction of the powdered fruit was done with $90 \%$ methanol. Rats were divided into five groups of five rats per group. Hyperglycaemia was induced using alloxan at a dose of $150 \mathrm{mg} / \mathrm{kg}$ in groups two to five. Groups one to five received distilled water $2 \mathrm{ml} / \mathrm{kg}$ (normal control), distilled water $2 \mathrm{ml} / \mathrm{kg}$ (diabetic control), $S$. anomalum extract $500 \mathrm{mg} / \mathrm{kg}$, S. anomalum extract $1,000 \mathrm{mg} / \mathrm{kg}$ and glibenclamide 10 $\mathrm{mg} / \mathrm{kg}$ respectively. The treatment was continued for 14 days during which blood glucose levels were monitored. Phytochemical screening revealed the presence carbohydrate, cardiac glycosides, saponins, tannins, flavonoids and alkaloids. The oral $\mathrm{LD}_{50}$ was found to be above $5,000 \mathrm{mg} / \mathrm{kg}$. The methanol extract of $S$. anomalum fruit at $1,000 \mathrm{mg} / \mathrm{kg}$ showed a statistically significant blood glucose lowering effect $(p<0.05)$ between the blood glucose level at zero hour $(337.8 \pm 29.4 \mathrm{mg} / \mathrm{dL})$ and blood glucose level after $24 \mathrm{~h}(317.4 \pm 21.5 \mathrm{mg} / \mathrm{dL})$ for the groups being administered with the extract. The groups receiving $500 \mathrm{mg} / \mathrm{kg}$ and $1,000 \mathrm{mg} / \mathrm{kg}$ of the extract showed a statistical significant blood glucose lowering $(p<0.05)$ between the blood glucose level at day zero $(329 \pm 34$ and $337 \pm 29 \mathrm{mg} / \mathrm{dL})$ was compared to the blood glucose at day $15(237 \pm 32$ and $143 \pm 15 \mathrm{mg} / \mathrm{dL})$. In conclusion, methanol extract of $S$. anomalum fruit contains one or more active agents that has anti-hyperglycaemic and hypoglcaemic activity in alloxan induced hyperglcaemic and normoglycaemic rats.
\end{abstract}

\section{Article Info \\ Accepted: 01 October 2016 Available Online: 06 October 2016}

\section{Ke ywords}

Diabetes mellitus

Hyperglycaemia

Hypoglycaemia

Methanol extract

Solanum anomalum

\section{Introduction}

Traditional Medicine is defined as 'the knowledge, skills and practices based on the theories, beliefs and experiences indigenous to different cultures, used in the maintenance of health and in the prevention, diagnosis, improvement or treatment of physical and mental illness' (WHO, 2000). Diabetes mellitus is a potentially morbid condition with high prevalence worldwide thus the disease constitutes a major health concern. The prevalence of the disease in the year 2000 is about $2.8 \%$ of the global population and is expected to rise to about 4.4\% by 2030 (American Diabetes Association, 2004). The search for compounds with novel properties to deal with the disease condition is still in progress (Etuk, 2010). Diabetes mellitus is a common and very prevalent disease affecting the citizens of both developed and developing countries. Direct cost of diabetes mellitus in 
Nigeria is put to about 150 billion naira annually (Suleiman et al., 2006). Recently, there has been a resurgent interest in the herbal treatments of diabetes. A good number of these plants used traditionally have been proofed beyond scientific doubt to have antidiabetic activity. This includes Herichrysum odoratissimum, Herichrysum nudifolium, Vernonia amygdalina, Vernonia oligocephala, Artemisia afra, Brachylaena discolor, Catharanthus roseus etc. (Erasto et al., 2005). This study is aimed at scientifically investigating the antidiabetic activity of the methanol extract of Solanum anomalum Thonn. fruits in experimental rats.

\section{Materials and methods}

\section{Collection of plant material and extraction}

The whole plant Solanum anomalum Thonn was collected from Shika village, Shika, Giwa local Government and was identified by Mallam Umar Gallah of the herbarium section in the Department of Biological Sciences, Ahmadu Bello University (ABU), Zaria, Nigeria. A voucher specimen was deposited for future reference with voucher number 723 . The fruits were removed from the plant and air dried for three weeks then crushed into powder. About $600 \mathrm{~g}$ of the powdered plant was extracted with $2.5 \mathrm{~L} 90 \% \mathrm{v} / \mathrm{v}$ methanol for 72 hrs using Soxhlet apparatus. The solvent was evaporated to give a yield of $107 \mathrm{~g}(17.8 \% \mathrm{w} / \mathrm{w})$ and the extract was stored in a desiccator until used.

\section{Animals}

Wistar rats of both sexes weighing 160-200 g obtained from the Animal House, Department of Pharmacology and Therapeutics, ABU Zaria were used for the study. The animals were maintained in a well ventilated room, fed on standard rodent feed and granted access to water ad-libitum. They were kept in clean cages under approximately 12/12 hrs normal light/dark cycle and allowed to acclimatize to the laboratory environment for a period of two weeks before commencement of the experiment. The experiments were performed after approval of the protocol by the Departmental Ethics Committee and were carried out in accordance with the current guidelines for the care of laboratory animals.

\section{Phytochemical screening}

Phytochemical screening was done as described in Trease and Evans (1983) Pharmacognosy.

\section{Acute toxicity studies in rats $\left(\mathbf{L D}_{\mathbf{5 0}}\right)$}

$\mathrm{LD}_{50}$ determinations were conducted using the method of Lorke (1983). In the initial phase, three groups of three rats each were treated with the methanol extract of the plant at doses of 10,100 and $1,000 \mathrm{mg} / \mathrm{kg}$ body weight orally and observed for signs of toxicity, and death for 24 hours. In the second phase, three fresh groups of one rat each were orally administered with 1,600, 2,900 and $5,000 \mathrm{mg} / \mathrm{kg}$ of the extract. The doses were based on the result obtained in the initial phase. The $\mathrm{LD}_{50}$ value was then determined by calculating the geometric mean of the lowest dose that caused death and the highest dose for which the animal survived.

\section{Alloxan-induced hyperglycaemia}

Alloxan- induced hyperglycaemia was conducted by employing the method as described by Okokon et al. (2006). Thirty five overnight fasted rats were administered alloxan monohydrate at a dose of 150 $\mathrm{mg} / \mathrm{kg}$ intraperitoneally. Blood samples were withdrawn at the time of injection to determine the initial fasting blood glucose concentration (FBGC) by pricking the tail tip arteries of the rats. Food and water containing 5\% dextrose was then immediately returned to them. The dextrose water was allowed to stay with the rats for only $24 \mathrm{hrs}$ to protect massive hypoglycaemia that will be seen as a result of excessive depletion of pancreatic beta cells containing insulin. The rats were then observed over a period of $72 \mathrm{hrs}$ for signs of hyperglycaemia. The fasting blood sugar was then taken and compared with the control. The determination of blood glucose concentration was done by the glucose oxidase principles (Beach and Turner, 1958). Those that were hyperglycaemic were then selected for the studies. A fasting blood sugar (FBS) of 180-350 mg/dL was considered suitable for the study (Okokon et al., 2006).

Effect of 14 days oral administration of $S$. anomalum on the blood glucose concentration of hyperglycaemic Wistar rats

The rats recruited for the study were then grouped into five groups each containing five rats with proportional FBS and weight. The first and second group which represents the normal control and the diabetic control group respectively were given normal saline at $2 \mathrm{ml} / \mathrm{kg}$ body weight orally; the third and fourth groups received $500 \mathrm{mg} / \mathrm{kg}$ and $1,000 \mathrm{mg} / \mathrm{kg}$ dosage of the methanol extract of $S$. anomalum fruit orally. The fifth group received glibenclamide $10 \mathrm{mg} / \mathrm{kg}$ orally. The extract of 
S. anomalum was administered to the rats immediately after the blood glucose level was taken; food and water were then returned to the rats. Blood was withdrawn from the tail tip artery for testing at interval of $0,1,3,6$, 12 and $24 \mathrm{hrs}$ for the first day using Accu-Check Glucometre and the advantage II Test strips and then continually administered their respected doses of normal saline, extract and glibenclamide as appropriate continually for fourteen days while weight and blood glucose level were monitored on the third, seventh and fifteenth day.

\section{Effect of acute single administration of methanol extract of $S$. anomalum fruit on the blood glucose concentration of normoglycaemic Wistar rats}

The rats were grouped into five rats per group of four groups. The control group was administered normal saline $2 \mathrm{ml} / \mathrm{kg}$ orally, groups two and three received 500 $\mathrm{mg} / \mathrm{kg}$ and $1,000 \mathrm{mg} / \mathrm{kg}$ doses of the methanol extract orally while group four received glibenclamide $10 \mathrm{mg} / \mathrm{kg}$ orally. The determination of blood glucose was done by the glucose oxidase principles (Beach and Turner, 1958) using Accu-Check Glucometre.

\section{Statistical analysis}

Results are expressed as the mean \pm standard error of mean. Statistical analysis of data was carried out using SPSS version 19. Analysis was done using One-way analysis of variance or student's t-test as appropriate. Differences in mean were considered to be significant when $p<0.05$. Values are represented as tables.

\section{Results and discussion}

Oral administration of the methanolic fruit extract of $S$. anomalum $(10-5,000 \mathrm{mg} / \mathrm{kg})$ did not produce any visible sign of toxicity or mortality in the animals over a period of $24 \mathrm{hrs}$ for both the first and second phase of the Lorke's method. The oral $\mathrm{LD}_{50}$ was therefore confirmed to be above $5,000 \mathrm{mg} / \mathrm{kg}$.

The oral $\mathrm{LD}_{50}$ was found to be above $5,000 \mathrm{mg} / \mathrm{kg}$ showing the high safety of the extract when used orally in rats. Medicinal plant extract have been valuable antidiabetic agent and may involve one or more active components responsible for blood glucose reduction (Marles and Farnsworth, 1995; Grover et al., 2002). There are a lot of reports implicating some phytochemical compounds as hypoglycaemic agent. Compounds like polypeptides (Khanna and Jain, 1981), alkaloids (Karawya and Wahab, 1984), flavonoids (Schimizu et al., 1984), polysaccharides (Tomoda et al., 1985), glycoprotein (Hikino et al., 1989), steroids (Ivorra et al., 1989), terpenoids (Reher et al., 1991) and tannins (Reher et al., 1991) have been shown to have blood glucose lowering activity. Saponins have a wide range of pharmacological activities which includes hypoglycaemic, expectorant, anti-inflammatory, vasoprotective, hypocholesterolemic, immunomodulatory, molluscicidal, antifungal, antiparasitic and many other effects (Sparg et al., 2004; Sahu et al., 2008).

Table 1. Phytochemical screening of methanolic extract of Solanum anomalum Thonn.

\begin{tabular}{lll}
\hline Phytochemical constituents & Test performed & Remarks \\
\hline Carbohydrate & Molisch test & + \\
Triterpenes & Test for triterpenes & - \\
Anthracene (free) & Bontragers test & - \\
Cardiac glycoside & Keller Killiani test & ++ \\
Saponins & Frothing test & ++ \\
& Haemolysis test & ++ \\
Tannins & Ferric chloride test & ++ \\
& Lead sub acetate test & + \\
Flavonoids & Ferric chloride test & ++ \\
& Sodium hydroxide test & + \\
Alkaloids & Meyer's test & + \\
& Dragendoff test & + \\
& Wagner's test & + \\
\hline$+=$ present, $++=$ conspicuously present, $-=$ absent. &
\end{tabular}


Preliminary phytochemical screening of fruit extract of $S$. anomalum has shown the presence of alkaloids, flavonoids, tannins, saponins among others (Table 1). The observed hypoglycaemic effect of this extract could have resulted from one or more of these compound present in the methanolic fruit extract of the plant.

Unlike glibenclamide, the extract showed a slight initial rise in blood glucose level during the first $3 \mathrm{hrs}$ before significantly $(p<0.05)$ reducing the blood glucose level at both doses $500 \mathrm{mg} / \mathrm{kg}$ and $1000 \mathrm{mg} / \mathrm{kg}$ (Table 2). The group receiving glibeclamide showed an immediate decline in blood glucose level. This may suggest that the damage done by alloxan to the pancreatic beta cells is not complete as sulphonylureas are established insulin secretagogue which causes insulin secretion by inhibition of an ATP-dependent potassium channel, $\mathrm{K}_{\mathrm{ATP}}$, which sets the $\beta$ cell resting membrane potential. A reduction of potassium outflow causes $\beta$ cell depolarization and the activation of one or more L-type calcium channels. The resulting calcium influx triggers exocytosis (AguilarBryan et al., 1995).

Table 2. Effect of single oral administration of methanol extract of Solanum anomalum Thonn. fruits on blood glucose level of hyperglycaemic Wistar rats.

\begin{tabular}{|c|c|c|c|c|c|c|c|}
\hline \multirow{2}{*}{ Treatment } & \multirow{2}{*}{$\begin{array}{l}\text { Dose } \\
(\mathrm{mg} / \mathrm{kg})\end{array}$} & \multicolumn{6}{|c|}{ Blood glucose level $(\mathrm{mg} / \mathrm{dL})($ Mean \pm SEM) } \\
\hline & & $\mathbf{O} \mathbf{h}$ & $1 \mathrm{~h}$ & $3 \mathrm{~h}$ & $6 \mathrm{~h}$ & $12 \mathrm{~h}$ & $24 \mathrm{~h}$ \\
\hline $\begin{array}{l}\text { Distilled water } \\
\text { (normal control) }\end{array}$ & $2 \mathrm{ml} / \mathrm{kg}$ & $112.3 \pm 7.4$ & $109.3 \pm 8.0$ & $103.3 \pm 4.0$ & $105.3 \pm 6.4$ & $111.3 \pm 3.4$ & $110.9 \pm 2.1$ \\
\hline $\begin{array}{l}\text { Distilled water } \\
\text { (diabetic control) }\end{array}$ & $2 \mathrm{ml} / \mathrm{kg}$ & $328.0 \pm 31.7$ & $340.2 \pm 31.3$ & $338.2 \pm 29.0$ & $342.8 \pm 22.8$ & $347.4 \pm 28.6$ & $348.0 \pm 23.6$ \\
\hline S. anomalum & 500 & $329.2 \pm 22.6$ & $346.6 \pm 33.3$ & $336.0 \pm 25.0$ & $328.2 \pm 23.4$ & $324.2 \pm 25.2$ & $315.8 \pm 29.8$ \\
\hline S. anomalum & 1000 & $337.8 \pm 29.4$ & $363.0 \pm 31.2$ & $351.0 \pm 30.3$ & $331.0 \pm 31.2$ & $323.4 \pm 30.9$ & $317.4 \pm 21.5^{*}$ \\
\hline Glibenclamide & 10 & $339.4 \pm 31.2$ & $332.0 \pm 30.4 *$ & $323.4 \pm 32.2 *$ & $312.4 \pm 30.0^{*}$ & $301.6 \pm 27.2 *$ & $287.6 \pm 26.5^{*}$ \\
\hline
\end{tabular}

$n=5$, * significant at $p<0.05$ vs Blood glucose level at $0 \mathrm{~h}, \mathrm{SEM}=$ standard error of mean.

The groups receiving $500 \mathrm{mg} / \mathrm{kg}$ and $1,000 \mathrm{mg} / \mathrm{kg}$ of the extract showed a statistically significant blood glucose lowering $(p<0.05)$ between the blood glucose level at day zero (329 \pm 34 and $337 \pm 29 \mathrm{mg} / \mathrm{dL})$ was compared to the blood glucose at day $15(237 \pm 32$ and $143 \pm 15 \mathrm{mg} / \mathrm{dL}$ ) (Table 3 ). One may also suggest enhancing insulin secretion as the possible mode of action of the extract. At the present juncture it is not possible to pinpoint the mechanism of anti hyperglycaemic action of the extract of S. anomalum. Since the blood glucose lowering effect of the extract of the fruit of $S$. anomalum was observed in alloxan hyperglycaemic rats as well as in fasted normal rats, this effect could, possibly be due to increased peripheral glucose utilization. Inhibition of the proximal tubular reabsorption mechanism for glucose in the kidney, if any, can also contribute towards blood lowering effect (Sharma et al., 2006).

Table 3. Effect of daily oral administration of methanol extract of Solanum anomalum Thonn. fruit on blood glucose level of hyperglycaemic Wistar rats.

\begin{tabular}{lllllll}
\hline \multirow{2}{*}{ Treatment } & $\begin{array}{l}\text { Dose } \\
(\mathbf{m g} / \mathbf{k g})\end{array}$ & \multicolumn{2}{l}{ Blood glucose level in mg/dL (Mean \pm SEM) } & & \\
\cline { 2 - 6 } & Day 0 & Day 1 & Day 3 & Day 7 & Day 15 \\
\hline $\begin{array}{l}\text { Distilled water } \\
\text { (normal control) }\end{array}$ & $2 \mathrm{ml} / \mathrm{kg}$ & $113 \pm 11$ & $102 \pm 10$ & $89 \pm 9$ & $103 \pm 12$ & $110 \pm 13$ \\
$\begin{array}{l}\text { Distilled water } \\
\text { (diabetic control) }\end{array}$ & $2 \mathrm{ml} / \mathrm{kg}$ & $328 \pm 31$ & $348 \pm 23$ & $355 \pm 25$ & $341 \pm 29$ & $383 \pm 34$ \\
S. anomalum & 500 & $329 \pm 34$ & $315 \pm 29^{*}$ & $296 \pm 24^{*}$ & $285 \pm 26^{*}$ & $237 \pm 32^{*}$ \\
S. anomalum & 1000 & $337 \pm 29$ & $317 \pm 21^{*}$ & $295 \pm 19^{*}$ & $278 \pm 22^{*}$ & $143 \pm 15^{*}$ \\
Glibenclamide & 10 & $338 \pm 31$ & $287 \pm 26^{*}$ & $248 \pm 27^{*}$ & $221 \pm 24^{*}$ & $139 \pm 18^{*}$ \\
\hline
\end{tabular}

$n=5$, * significant at $p<0.05$ vs Blood glucose level at Day 0, SEM = standard error of mean. 


\section{Conclusion}

In conclusion, results of the present study showed that methanol extract from $S$. anomalum fruit has, orally produced acute hypoglycaemic effects in healthy and alloxan-diabetic Wistar rats. The daily oral administration of this preparation also normalizes the glycaemia of mild diabetic rats after 14 days of treatment.

\section{Conflict of interest statement}

Authors declare that they have no conflict of interest.

\section{References}

Aguilar-Bryan, L., Nichols, C., Wechsler, S., Clementivj, P., Body, A.E., Gonzalez, G., Herreraspsa, H., 1995. Cloning of the beta cell high-affinity sulfonylurea receptor: A regulator of insulin secretion. Science. 268, 423-426.

American Diabetes Association, 2004. Global prevalence of diabetes estimates for the year 2000 and projections for 2030. Diabet. Care. 27, 1047-1053.

Beach, E.F., Turner, J.J., 1958. An enzymatic method for glucose determination in blood fluids. Clin. Chem. 4, 462468.

Erasto, P., Adebola, P.O., Grierson, D.S., Afolayan, A.J., 2005. An ethnobotanical study of plants used for the treatment of diabetes in the Eastern Cape Province, South Africa. Afr. J. Biotechnol. 4(12), 1458-1460.

Etuk, E.U., 2010. Animal models for studying diabetes mellitus. Agric. Biol. J. North America 1(2), 130-134.

Grover, J.K., Yadav, S., Vats, V., 2002. Medicinal plants of India with hypoglycemic potentials. J. Ethnopharmacol. 81, 81-100.

Hikino, H., Kobayashi, M., Suzuki, Y., Konno, C., 1989. Mechanism of hypoglycaemic activity of Aconitan A, a glycan from Aconitum carmichaeli roots. J. Ethnopharmacol. 25, 295-304.

Ivorra, M.D., Paya, M., Villar, A., 1989. A review of natural products and plants as potential antidiabetic agent. J. Ethnopharmacol. 27, 243-275.

Karawya, M.S., Wahab, S.A., 1984. Diphenylamine, an antihyperglycaemic agent from onion and tea. J. Nat.
Prod. 47, 775-780.

Khanna, P. and Jain, S., 1981. Hypoglycaemic activity of polypeptide-P from a plant source. J. Nat. Prod. 44, 648655.

Lorke, D., 1983. Anew approach to practical acute toxicity testing. Arch. Toxicol. 54, 275-287.

Marles, R., Farnsworth, N., 1995. Antidiabetic plants and their active constituents. Phytomed. 2, 137-165.

Okokon, J.E., Obut, J., Ikpatt, I., 2006. Antidiabetic activity of ethanolic leaf extract of Croton zambesicus Mueil (Thunder plant) in alloxan diabetic rats. Afr. J. Trad. Compl. Alter. Med. 2, 21-26.

Reher, G., Slijepcevic, M., Krans, L., 1991. Hypoglycaemic activity of triterpenes and tannins from Sarcopoterium spinosum and two Sanguirsorba species. Planta Med. 57, A57-A58.

Sahu, N.P., Banerjee, S., Mondal, N.B., Mandal, D., 2008. Steroidal saponins. In: Fortschritte der Chemie Organischer Naturstoffe / Progress in the Chemistry of Organic Natural Products. Vol. 89. Springer, Vienna. pp. 45-141.

Schimizu, M., Ito, T., Rshima, S., Mayashi, T., Arisawa, M., Morita, K.S., Ito Hasimato, Y., 1984. Inhibition of lens aldose reductase by flavonoids. Phytochem. 23, 18851888.

Sharma, S.B., Nasir, A., Prabhu, K.M., Murthy, P.S., 2006. Antihyperglycaemic effect of the fruit-pulp of Eugenia jambolana in experimental diabetes mellitus. J. Ethnopharmacol. 104, 367-373.

Sparg, S.G., Light, M.E., Staden, J., 2004. Biological activities and distribution of plant saponins. J. Ethnopharmacol. 94, 219-243.

Suleiman, I.A., Fadake, O.F., Okubanjo, O.O., 2006. Pharmacoeconomic evaluation of antidiabetic therapy in a Nigerian tertiary health institution. Ann. Afr. Med. 5(3), 135-137.

Tomoda, M., Shimada, K., Konno, C., Hikino, H., 1985. Structure of panaxan B, a hypoglycaemic glycan of Panax ginseng root. J. Ethnopharmacol. 24, 2431-2433.

Trease, G.E., Evans, M.C., 1983. Drugs of Biological Origin. In: A Text Book of Pharmacognosy. 12 ${ }^{\text {th }}$ Edn. (Eds.: Trease, G.E., Evans, W.C.), Bailliere Tindall, London. pp. 685-682.

WHO, 2000. General Guidelines for Methodologies on Research and Evaluation of Traditional Medicine. pp.1-20.

\section{How to cite this article:}

Bilyaminu, A., Helen, K., Umar, Z. A., 2016. Phytochemical screening and hypoglycaemic effect of methanol extract of Solanum anomalum Thonn. fruits in alloxan induced hyperglycaemic and normal Wistar rats. Int. J. Curr. Res. Biosci. Plant Biol. 3(10), 169-173. doi: http://dx.doi.org/10.20546/ijcrbp.2016.310.021 